\title{
Política Pública e Direito à Educação Infantil DE BoA Qualidade: A SITUAÇÃO DAS UMEIS NA MUNICIPALIDADE DE BELO HORIZONTE
}

\author{
Lucas Salles Moreira Rocha* \\ Márcio Luis de Oliveira* *
}

\begin{abstract}
1 Introdução. 2 A educação como direito fundamental e como direito humano prestacional. 3 Os direitos fundamentais prestacionais e seus custos: o ensino infantil de qualidade na municipalidade de Belo Horizonte. 4 Planejamento e políticas públicas como meios de concretização do direito fundamental de acesso ao ensino infantil de boa qualidade. 4.1 Montagem da agenda. 4.2 Instrumentos para formulação de políticas públicas. 4.3 Proposta de formulação de política pública. 5 Conclusão. Referências.
\end{abstract}

\section{RESUMO}

O tema do artigo centra-se na dificuldade da municipalidade de Belo Horizonte - Estado de Minas Gerais, Brasil - em assegurar a universalização do acesso ao ensino infantil de qualidade em suas Unidades Municipais de Educação Infantil (UMEIs), o que tem causado grande volume de ações judiciais em face da municipalidade, inviabilizando a adequada gestão administrativa da questão. Nesse contexto, o estudo sugere a adoção do "subsídio escolar" como política pública complementar, a título transitório ou permanente, para solucionar ou reduzir os efeitos negativos da situação. Na elaboração do artigo, foi utilizada a metodologia analítico-descritiva do problema fático-jurídico, com o apoio de métodos jurídico-dogmáticos e com a apresentação de dados estatísticos, além da consulta à legislação, à jurisprudência e à doutrina. $\mathrm{O}$ artigo tem como marco teórico estruturante o acesso universal ao ensino infantil de boa qualidade como direito fundamental e direito humano a ser viabilizado pelo Estado, com a colaboração da iniciativa privada. A partir do marco teórico, aborda-se a questão dos custos para a implementação dos direitos prestacionais primários e da necessidade de adoção de políticas públicas que contribuam, de modo sustentável, para a ampliação do acesso às escolas infantis de qualidade.

Palavras-chave: Ensino infantil. Ensino fundamental. Direito à educação. Direitos prestacionais primários. Universalização do direito à educação. Políticas públicas em educação.

* Mestre em Direito pela Faculdade de Direito Milton Campos (FDMC). Pós-Graduado em Direito Corporativo pelo Instituto Brasileiro de Mercado de Capitais (IBMEC-MG). Graduado em Direito pela Faculdade de Direito Milton Campos (FDMC). Advogado. E-mail: <rocha.lucas@gmail.com>.

** Doutor e Mestre em Direito. Professor da Universidade Federal de Minas Gerais (UFMG), da Escola Superior Dom Helder Câmara (ESDHC) e da Faculdade de Direito Milton Campos (FDMC). Advogado e Consultor Jurídico.E-mail: <marcio.luis@uol.com.br>. 


\section{INTRODUÇÃO}

A Constituição da República Federativa do Brasil determina que a educação é um direito de todos e um dever do Estado (art. 205). Seguindo essa diretriz, a própria Constituição, de forma pontual e objetiva, preceitua que o Estado tem a obrigação de garantir educação infantil, em creche e pré-escola, às crianças com até cinco anos de idade (art. 208, inc. IV) (BRASIL, 1988).

Não obstante as previsões constitucionais e a natureza fundamental do direito de acesso à educação de boa qualidade, esse direito, por ter um custo financeiro elevado, acaba se revelando inefetivo por causa de deficiências financeiro-administrativas na sua prestação pelo ente estatal. Esse problema vem sendo enfrentado pelo Município de Belo Horizonte, especificamente no que tange ao acesso às escolas infantis de qualidade.

A Prefeitura Municipal de Belo Horizonte, com o apoio do Internacional Finance Corporation (IFC) e do Banco Nacional de Desenvolvimento Econômico e Social (BNDES), desenvolveu as chamadas Unidades Municipais de Educação Infantil (UMEIs), originadas de política pública consubstanciada em Parceria Público-Privada (BELO HORIZONTE, 2017). Além de pioneiro no Brasil, o projeto tem fomentado a inclusão e equidade socioeconômica com reflexos sociais bastante positivos para a cidade, especialmente pela alta qualidade dos serviços de educação infantil prestados no âmbito das UMEIs.

Entretanto, mencionadas instituições não estão sendo capazes de suprir toda a demanda social, em decorrência da ausência de vagas suficientes. Por conseguinte, um enorme contingente judicial tem surgido em face do Município, proveniente da insatisfação dos pais de crianças que não conseguem vagas para seus filhos.

Atento às demandas sociais, o Município de Belo Horizonte tem investido progressivamente na expansão do seu sistema de ensino pré-escolar. Contudo, o enorme e crescente número de ações judiciais que têm condenado o Município a providenciar novas vagas nas escolas demonstra que as políticas públicas adotadas, pelo menos até o momento, não estão sendo capazes, por si só, de solucionar ou de minimizar o problema da acessibilidade às UMEIs.

Considerando que o Estado tem a obrigação constitucional de garantir acesso ao ensino básico a todos e que as decisões judiciais proferidas contra o Município de Belo Horizonte o desviam do seu planejamento, podendo causar, com efeito, graves prejuízos à municipalidade e à sociedade, mostra-se pertinente uma abordagem complementar àquela que vem sendo adotada, apta a contribuir para a solução ou a minimização do problema, de modo a permitir que, a médio prazo, o Município venha a implementar políticas públicas que possam garantir a acessibilidade sustentável ao serviço de ensino infantil de qualidade.

Partindo, pois, desse tema-problema (a inacessibilidade ao ensino infantil de qualidade e o ativismo judicial que lhe corresponde), o estudo apresenta duas hipóteses para a solução ou minimização temporária dos efeitos negativos dessa inacessibilidade, agravada pelo excessivo ativismo judicial quanto à questão: 
a) o oferecimento de vouchers, ou cartas de crédito aos responsáveis legais das crianças;

b) a concessão de valores monetários, ou espécie de bolsa de educação aos responsáveis legais das crianças.

Assim, o artigo busca contextualizar a universalização do acesso à educação infantil de boa qualidade como direito fundamental e direito humano para, em seguida, demonstrar como esse direito vem sendo implementado na municipalidade de Belo Horizonte, por meio das UMEIs. $O$ trabalho pretende abordar o problema da inacessibilidade às UMEIs de modo a propor medidas pontuais e temporárias que possam solucionar ou minimizar os efeitos negativos tanto da inacessibilidade quanto do ativismo judicial que lhe é correlato.

Na elaboração do artigo, foi utilizada a metodologia analítico-descritiva do problema fático-jurídico, com o apoio de métodos jurídico-dogmáticos e com a apresentação de dados estatísticos, além da consulta à legislação, à jurisprudência e à doutrina. Apesar de se ter referenciado, no artigo, o pensamento de Milton Friedman e a experiência do Bolsa Família como hipóteses de solução para o tema-problema, o artigo tem como marco teórico estruturante o acesso universal ao ensino infantil de boa qualidade como direito fundamental e direito humano a ser viabilizado pelo Estado, com a colaboração da iniciativa privada.

Além da introdução e das considerações finais, o artigo está organizado em três tópicos. No primeiro deles, o acesso à educação de boa qualidade é apresentado como direito prestacional fundamental e direito humano. No segundo item, é abordada a questão dos custos dos direitos prestacionais primários, com foco na situação das UMEIs na municipalidade de Belo Horizonte. No item seguinte, o artigo versa sobre sua temática principal, considerando a problematização em relação ao acesso ao ensino infantil de qualidade, por meio de adoção de políticas públicas complementares àquelas que já vêm sendo adotadas.

\section{A EDUCAÇÃO COMO DIREITO FUNDAMENTAL E COMO DIREITO HUMANO PRESTACIONAL}

O direito à educação é resultado da conquista de direitos, garantias e deveres de segunda dimensão, no contexto do constitucionalismo social, característico da primeira metade do século XX. Desde então, prerrogativas jurídico-sociais passaram a ser incluídas no rol das normas constitucionais fundamentais, norteando as intervenções do Estado nos setores econômico e social, tanto nos países de tradição liberal quanto comunitarista (OLIVEIRA, 2016, p. 186). Ao discorrer sobre as bases jurídicas do constitucionalismo social, Oliveira diz que

Aquela nova dimensão de direitos, garantias e deveres fundamentais passava a incluir dois grandes segmentos de conquistas jurídicas na modernidade ocidental: a) a proteção legislativa e fiscalizadora do trabalhador e das associações (sindicatos) dos trabalhadores contra o abuso das práticas liberais da época; $b$ ) a universalização progressiva do acesso à educação, ao sistema de tratamento de doenças, à infraestrutura sanitária e habitacional, à assistência social e à previdência social. Logo, a proteção do trabalhador e dos sindicatos gerava ônus 
(deveres) tanto para a iniciativa privada (patrões) quanto para o Estado (dever de fiscalização e execução das normas trabalhistas). Mas parcela significativa dos direitos e garantias sociais de segunda dimensão (educação, saúde, previdência etc.) impunha deveres imediatos ao próprio Estado, que assumia o encargo histórico-civilizacional de sua efetiva regulação e implementação material. Portanto, diferentemente dos direitos e garantias de primeira dimensão - que exigiam, basicamente, a atuação prestacional secundária do Estado (manutenção da segurança pública e privada para a preservação da incolumidade física, da intimidade, da liberdade, da propriedade etc.) -, os direitos e garantias de segunda dimensão (prerrogativas de substrato social) demandavam a efetiva atuação prestacional primária do Estado, ou seja, a elaboração legislativa e, preponderantemente, a implementação administrativa (com ou sem a participação da iniciativa privada) de medidas políticas, econômicas, sociais e jurídicas para tornarem efetivos o exercício e a fruição dos direitos e garantias sociais (OLIVEIRA, 2016, p. 205).

Não obstante a ampliação de direitos coletivos, o constitucionalismo social apresentou, historicamente, duas grandes vertentes: a) a totalitária, de ideologia socialista (ex.: União das República Socialistas Soviéticas) e fascista (ex.: Itália e Alemanha); b) a democrática, posteriormente designada e consolidada como social-democracia nos países escandinavos (OLIVEIRA, 2016, p. 183-190).

Em sua matriz democrática, o constitucionalismo social contribuiu para a atuação direta e indireta do Estado nas relações socioeconômicas, de forma a promover, em um ambiente político de liberdades públicas e privadas, a implementação e o acesso aos direitos sociais prestacionais e à proteção aos trabalhadores, por meio de ações interventivas do Estado na economia e pelo aumento e pelo redimensionamento dos gastos públicos (KERSTENETZKY, 2012, p. 37-57). No cenário do constitucionalismo social-democrata, o Estado passou a adotar medidas necessárias à redução das desigualdades socioeconômicas na tentativa de concretização progressiva dos direitos sociais mínimos aos indivíduos e à sociedade (OLIVEIRA, 2016, p. 197-210)

A partir de suas origens, o constitucionalismo social-democrático adaptou-se, em suas premissas e resultados, ao ambiente político, econômico e jurídico da segunda metade do século XX e, apesar de todos os contratempos, teve fundamental importância para o surgimento do atual Estado Democrático-Constitucional de Direito (OLIVEIRA, 2016, p. 195-197).

Atualmente, o direito fundamental de acesso à educação está plenamente consolidado como prerrogativa individual e coletiva, sendo ônus do Estado e da sociedade garanti-lo e promovê-lo de forma inclusivo-universal e de boa qualidade. Esse direito também foi alçado ao status de direito humano pela Declaração Universal dos Direitos Humanos, ${ }^{1}$ proclamada pela Assembleia Geral das Nações Unidas, em 10 de dezembro de 1948. Esse diploma jurídico, que inspirou as Constituições de muitos Estados e democracias no mundo, foi o primeiro de vários outros tratados internacionais globais e regionais adotados desde o fim da Segunda Guerra Mundial, versando, em algum aspecto, sobre o direito de acesso à educação. ${ }^{2} \mathrm{~A}$ importância desse direito, especificamente no âmbito do ensino básico, é 
retratada de forma esclarecedora por Soo-Hyang Choi, Diretora da Seção de Educação Infantil da UNESCO:

De acordo com o estudo da primeira infância "Abecedarian" (MASSE; BARNETT, 2003) nos EUA, por exemplo, as crianças que freqüentaram a pré-escola ${ }^{3}$ têm maior probabilidade de alcançar melhores resultados em testes de raciocínio e de chegar até a educação superior, do que aquelas que não participaram. Elas poderão ser contratadas para empregos com melhor remuneração no futuro, como conseqüência disso.

O projeto "Perry Pre-school", bem conhecido nos EUA, também relata resultados semelhantes. As crianças que participaram de programas de qualidade na primeira infância têm maior probabilidade de completar o ensino médio, ingressar na educação superior, ter treinamento profissional ou conseguir um emprego. O estudo também mostra que os programas da primeira infância são eficientes em prevenir que a criança se envolva em problemas sociais. As crianças que participaram do projeto "Perry Pre-school" tiveram menor probabilidade de serem classificadas como portadoras de retardo mental, serem presas, acusadas de cometerem crimes graves ou depender da assistência social. Desta maneira, os benefícios foram múltiplos, nos âmbitos educacional, econômico e social (CHOI, 2004, p. 19).

Para que a norma constitucional alcance os seus objetivos de emancipação e plenipotencialização do ser humano por intermédio da educação (OLIVEIRA, 2016, p. 95-101), faz-se necessária a participação do Estado e da sociedade civil, de modo a tornar efetiva a promoção de acessibilidade universal ao sistema de ensino de boa qualidade em todos os seus níveis e, mais especificamente, no âmbito da educação infantil e fundamental.

A Constituição prevê, de forma direta, que o acesso ao ensino infantil (crianças de até cinco anos de idade) é direito público subjetivo e, ainda, que o seu não oferecimento, ou oferta irregular, importa responsabilidade da autoridade competente (art. 208, IV e $\S 2^{\circ}$ ). Assim, o direito à educação infantil pode ser exigido pelo particular em face do Estado. Esse entendimento foi adotado pelo Supremo Tribunal Federal no julgamento do Recurso Extraordinário n ${ }^{\circ}$ 464.143-SP, de relatoria da Ministra Ellen Gracie, e do Recurso Extraordinário $n^{\circ}$ 384.201-SP, de relatoria do Ministro Marco Aurélio, respectivamente:

DIREITO CONSTITUCIONAL E DIREITO DA CRIANÇA E DO ADOLESCENTE. [...] GARANTIA ESTATAL DE VAGA EM CRECHE. PRERROGATIVA CONSTITUCIONAL. AUSÊNCIA DE INGERÊNCIA NO PODER DISCRICIONÁRIO DO PODER EXECUTIVO. PRECEDENTES. 1. A educação infantil é prerrogativa constitucional indisponível, impondo ao Estado a obrigação de criar condições objetivas que possibilitem o efetivo acesso a creches e unidades pré-escolares. 2. É possível ao Poder Judiciário determinar a implementação pelo Estado, quando inadimplente, de políticas públicas constitucionalmente previstas, sem que haja ingerência em questão que envolve o poder discricionário do Poder Executivo. 3. Agravo regimental improvido (BRASIL, 2010a, online). 
CRECHE E PRÉ-ESCOLA - OBRIGAÇÃO DO ESTADO. Cumpre ao Estado gênero - proporcionar a creche e a pré-escola às crianças de zero a cinco anos de idade, observando a norma cogente do artigo 208, inciso IV, da Constituição Federal, com a redação decorrente da Emenda Constitucional no 53/2006 (BRASIL, 2007, online).

A garantia à educação infantil para crianças de até cinco anos de idade está prevista, ainda, no artigo 54 da Lei no 8.069, de 1990, que dispõe sobre o Estatuto da Criança e do Adolescente, e no artigo $4^{\circ}$ da Lei no 9.394, de 1996, que estabelece as diretrizes e bases da educação nacional, conforme se infere dos seguintes dispositivos: "Art. 54. É dever do Estado assegurar à criança e ao adolescente: [...] IV - atendimento em creche e pré-escola às crianças de zero a cinco anos de idade." (BRASIL, 1990, online). "Art. $4^{\circ}$ O dever do Estado com educação escolar pública será efetivado mediante a garantia de: [...] II - educação infantil gratuita às crianças de até 5 (cinco) anos de idade.” (BRASIL, 1996, online).

Com base nos artigos de lei acima transcritos, o Superior Tribunal de Justiça, reforçando o entendimento de que o oferecimento de educação infantil gratuita é um dever do Estado, proferiu as seguintes decisões no julgamento do Recurso Especial n ${ }^{\circ}$ 510.598-SP e $\mathrm{n}^{\mathrm{o}}$ 577.573-SP, ambos de relatoria do Ministro João Otávio de Noronha: ${ }^{4}$

RECURSO ESPECIAL. AÇÃO CIVIL PÚBLICA ARTIGOS 54 E 208 DO ESTATUTO DA CRIANÇA E DO ADOLESCENTE. MATRÍCULA E FREQÜÊNCIA DE MENORES DE ZERO A SEIS ANOS EM CRECHE DA REDE PÚBLICA MUNICIPAL. 1. O Estatuto da Criança e do Adolescente (Lei n. 8.069/90) e a Lei de Diretrizes e Bases da Educação (Lei n. 9.394/96, $\left.\operatorname{art.} 4^{\circ}, I V\right)$ asseguram o atendimento de crianças de zero a seis anos em creches e pré-escolas da rede pública. 2. Compete à Administração Pública propiciar às crianças de zero a seis anos acesso ao atendimento público educacional e a freqüência em creches, de forma que, estando jungida ao princípio da legalidade, é seu dever assegurar que tais serviços sejam prestados mediante rede própria. 3. "Consagrado por um lado o dever do Estado, revela-se, pelo outro ângulo, o direito subjetivo da criança. Consectariamente, em função do princípio da inafastabilidade da jurisdição consagrado constitucionalmente, a todo direito corresponde uma ação que o assegura, sendo certo que todas as crianças nas condições estipuladas pela lei encartam-se na esfera desse direito e podem exigi-lo em juízo" (REsp n. 575.280-SP, relator para o acórdão Ministro Luiz Fux, DJ de 25.10.2004). [...] (BRASIL, 2008a, online).

RECURSO ESPECIAL. AÇÃO CIVIL PÚBLICA ARTIGOS 54 E 208 DO ESTATUTO DA CRIANÇA E DO ADOLESCENTE. MATRÍCULA E FREQÜÊNCIA DE MENORES DE ZERO A SEIS ANOS EM CRECHE DA REDE PÚBLICA MUNICIPAL. 1. O Estatuto da Criança e do Adolescente (Lei n. 8.069/90) e a Lei de Diretrizes e Bases da Educação (Lei n. 9.394/96, $\left.\operatorname{art.} 4^{\circ}, \mathrm{IV}\right)$ asseguram o atendimento de crianças de zero a seis anos em creches e pré-escolas da rede pública. 2. Compete à Administração Pública propiciar às crianças de zero a seis anos acesso ao atendimento público educacional e a freqüência em creches, de forma que, estando jungida ao princípio da legalidade, é seu dever assegurar que tais serviços sejam prestados mediante rede própria. [...] (BRASL, 2008b, online). 
No caso específico do Município de Belo Horizonte, a própria Lei Orgânica estabelece que é dever do Município garantir atendimento gratuito em creche e pré-escola às crianças de, nesse caso, até seis anos de idade, conforme se infere do seu artigo 157:

Art. 157 - A educação, direito de todos, dever do Poder Público e da sociedade, tem como objetivo o pleno desenvolvimento do cidadão, tornando-o capaz de refletir sobre a realidade e visando à qualificação para o trabalho.

$\S 1^{\circ}$ - O dever do Município com a educação implica a garantia de:

$[\ldots]$

II - atendimento obrigatório e gratuito em creche e pré-escola às crianças de zero a seis anos de idade, em horário integral, bem como acesso automático ao ensino de primeiro grau. (BELO HORIZONTE, 1990, online).

No referido Município, existe um expressivo movimento de judicialização do direito de crianças de até cinco anos terem acesso ao ensino básico, pelo ingresso nas chamadas Unidades Municipais de Educação Infantil (UMEIs), que são implementadas por meio de Parceria Público-Privada. Alguns pais, inconformados com a impossibilidade de matricular seus filhos nesse sistema de ensino municipal de qualidade, têm pleiteado tal direito junto ao Poder Judiciário. De forma bastante consistente, o Tribunal de Justiça de Minas Gerais vem decidindo pela obrigatoriedade, pelo Município, de conceder tais vagas aos demandantes. É o que se infere das decisões proferidas nas Apelações Cíveis no 1.0024.16.043475-9/001, de relatoria do Desembargador Judimar Biber, e no 1.0024.15.209676-4/001, de relatoria do Desembargador Afrânio Vilela, respectivamente:

APELAÇÃO CÍVEL - [...] AÇÃO DE OBRIGAÇÃO DE FAZER - DIREITO À EDUCAÇÃO-MENOR-CRECHE-UMEI-GARANTIACONSTITUCIONAL - LEIORGÂNICA DOMUNICÍPIO DE BELO HORIZONTE - ECA - CRECHE PARTICULAR - SOMENTE AS CONVENIADAS. A educação é direito de todos e dever do Estado e da família e deve ser promovida e incentivada com a colaboração da sociedade, visando ao pleno desenvolvimento da pessoa, seu preparo para o exercício da cidadania e sua qualificação para o trabalho. A Lei orgânica do Município de Belo Horizonte garante em seu artigo 157, §1 $1^{\circ}$, II, atendimento obrigatório e gratuito em creche e pré-escola às crianças de zero a seis anos de idade, sendo que o Estatuto da Criança e do Adolescente em seu art. 53, V, assegura à criança e ao adolescente, o acesso à escola pública e gratuita próxima de sua residência, ou particular conveniada. No reexame necessário, rejeitadas as preliminares e, no mérito, reformada em parte a sentença, prejudicado o recurso voluntário (MINAS GERAIS, 2017, online).

REEXAME NECESSÁRIO E APELAÇÃO CÍVEL - MANDADO DE SEGURANÇA - MATRÍCULA EM UMEI - COMPETÊNCIA DA VARA DA INFÂNCIA E DA JUVENTUDE - CRIANÇA - MATRÍCULA NEGADA - ARTIGOS 205, 208, VI, DA CONSTITUIÇÃO FEDERAL E ESTATUTO DA CRIANÇA E DO ADOLESCENTE - DEVER DO MUNICÍPIO - DIREITO LÍQUIDO E CERTO - VIOLAÇÃO - SENTENÇA PARCIALMENTE REFORMADA. 1. A competência para julgamento de mandado de segurança 
com objetivo de assegurar a matrícula de menor em instituição de ensino é da Justiça da Infância e da Juventude, nos termos dos artigos 148, IV e 209, do Estatuto da Infância e da Juventude. 2. É dever do Município a concessão de vaga em creche pública, porquanto compreende o direito à educação, assegurado pela Constituição Federal e pelo Estatuto da Criança e do Adolescente. 4. Demonstrada a violação do direito líquido e certo da impetrante de acesso à educação, por ato ilegal praticado pela autoridade coatora, correta a sentença, no ponto em que determinou a matrícula dela na UMEI apontada na inicial ou em outra próxima de sua residência (MINAS GERAIS, 2016, online).

De fato, o expressivo volume de ações judiciais dessa natureza movidas contra o $\mathrm{Mu}$ nicípio de Belo Horizonte ${ }^{5}$ explicita que, atualmente, as políticas públicas adotadas estão sendo incapazes de garantir a todos o acesso ao ensino infantil de qualidade. Buscar-se-á, nesse sentido, explorar adiante a questão dos custos dos direitos prestacionais primários, para, posteriormente, sugerir política pública que contribua para o acesso universal ao ensino infantil de boa qualidade.

\section{OS DIREITOS FUNDAMENTAIS PRESTACIONAIS E SEUS CUSTOS: O ENSINO INFANTIL DE QUALIDADE NA MUNICIPALIDADE DE BELO HORIZONTE}

Ao abordar o tema dos custos financeiros de implementação dos direitos, Galdino respalda sua análise a partir da concepção mista ou eclética de direitos subjetivos de Jellinek (GALDINO, 2005, p. 129), para quem o conceito de direito subjetivo inclui dois elementos: o interesse (elemento objetivo) e a vontade (elemento subjetivo). O direito subjetivo se expressaria como interesse juridicamente protegido e pela potencialidade de o seu titular querer exercê-lo (GALDINO, 2005, p. 129). Esse direito, se exercido, seria garantido pela tutela do Estado, em regra, pela Administração Pública ou pelo Poder Judiciário.

Amparado em doutrina majoritária, Galdino (GALDINO, 2005, p. 148-149) faz menção ao fato de que os direitos fundamentais podem ainda ser classificados em direitos positivos e direitos negativos. Para o autor, diferentemente da categoria de direitos subjetivos - em que se aufere a possibilidade, ou não, de exercício de determinado direito -, esses dois outros qualificativos consideram se o direito respectivo resultará em uma obrigação de fazer, ou não fazer, por parte do Estado. Um exemplo de obrigação de não fazer (obrigação negativa), por parte do Estado, seria o de não tolher a manifestação de pensamento por parte dos indivíduos (art. $5^{\circ}$, inciso IV, da Constituição), ou de não violar os direitos destes por motivo de crença (art. $5^{\circ}$, inciso VII, da Constituição). A obrigação de fazer do Estado (obrigação positiva), por outro lado, pode ser exemplificada pelo já citado dever de garantir a todos o acesso à educação (art. 205 e seguintes da Constituição).

Conforme se percebe, as obrigações negativas não geram qualquer custo para o Estado, pois, em decorrência destas, este deve apenas se abster de tomar determinadas medidas. As obrigações positivas, por seu turno, geram encargos para o Estado, que terá a obrigação de 
realizar atos prestacionais (dispor de recursos financeiros, patrimoniais, operacionais, etc.) para garantir o efetivo direito concedido à sociedade e aos seus integrantes.

Essa distinção é importante, pois, conforme a ciência econômica, a escassez de recursos necessários à sobrevivência humana é um fator condicionante da conduta das sociedades e dos indivíduos, que agem a partir de suas necessidades próprias, em busca dos recursos finitos, necessários não apenas à sua sobrevivência, mas também à satisfação de outras vontades (WONNACOTT; WONNACOTT, 1985, p. 23-25).

Sob essa ótica, os bens podem ser classificados como "livres" ou "econômicos". Os bens livres são aqueles sobre os quais, por qualquer razão, e em determinado contexto, não se submetem à escassez (como o oxigênio, por ora). Bens econômicos são aqueles dotados de utilidade que sofrem os efeitos da escassez, como diamantes (GALDINO, 2005, p. 159). Importante reparar, ante os exemplos citados, que o elemento que diferencia os bens livres dos bens econômicos não é a importância que se atribui a estes para fins de sobrevivência humana, mas a sua acessibilidade ampla ou restrita. A título elucidativo, percebe-se que, não obstante o oxigênio atmosférico ser mais importante à sobrevivência humana do que os diamantes, a estes é atribuído um valor econômico, enquanto àquele não.

Logo, a escassez é potencializadora de conflitos entre os indivíduos e as sociedades, que lutam para obter maior acesso aos bens econômicos. Por conseguinte, a sociedade e, principalmente, o Estado organizam-se em torno dos recursos disponíveis para direcioná-los e satisfazer, da forma mais adequada possível, as necessidades humanas (GALDINO, 2005, p. 156-157).

Para Galdino (2005, p. 158-159), o potencial conflito em torno dos bens escassos pode ser observado sob vários prismas e, em especial, sob o do agente político e o do Direito. No primeiro caso (sob a ótica do agente político), o conflito envolveria o âmbito da tomada de decisão política, direcionada à solução de um determinado problema de interesse do Estado (a escolha do interesse e os meios para se realizá-lo de modo efetivo). Na segunda hipótese, o conflito envolveria eventualmente um aparente confronto entre direitos.

Sobre essa questão, o Superior Tribunal de Justiça, no julgamento do Recurso Especial n ${ }^{\mathrm{o}}$ 1.185.474-SC, de relatoria do Mininistro Humberto Martins, consolidou o seguinte entendimento:

[...] CONSTITUCIONAL. ACESSO À CRECHE AOS MENORES DE ZERO A SEIS ANOS. DIREITO SUBJETIVO. RESERVA DO POSSÍVEL. TEORIZAÇÃO E CABIMENTO. IMPOSSIBILIDADE DE ARGUIÇÃO COMO TESE ABSTRATA DE DEFESA. ESCASSEZ DE RECURSOS COMO O RESULTADO DE UMA DECISÃO POLÍTICA. PRIORIDADE DOS DIREITOS FUNDAMENTAIS. CONTEÚDO DO MÍNIMO EXISTENCIAL. ESSENCIALIDADE DO DIREITO À EDUCAÇÃO. PRECEDENTES DO STF E STJ. 1. A tese da reserva do possível assenta-se em ideia de que, desde os romanos, está incorporada na tradição ocidental, no sentido de que a obrigação impossível não pode ser exigida (Impossibilium nulla obligatio est - Celso, D. 50, 17, 185). Por tal motivo, a insuficiência de recursos orçamentários não pode ser considerada uma mera falácia. 2 . Todavia, observa-se que a dimensão fática da reserva do possível é questão intrinsecamente vin- 
culada ao problema da escassez. Esta pode ser compreendida como "sinônimo" de desigualdade. Bens escassos são bens que não podem ser usufruídos por todos e, justamente por isso, devem ser distribuídos segundo regras que pressupõe o direito igual ao bem e a impossibilidade do uso igual e simultâneo. 3. Esse estado de escassez, muitas vezes, é resultado de um processo de escolha, de uma decisão. Quando não há recursos suficientes para prover todas as necessidades, a decisão do administrador de investir em determinada área implica escassez de recursos para outra que não foi contemplada. A título de exemplo, o gasto com festividades ou propagandas governamentais pode ser traduzido na ausência de dinheiro para a prestação de uma educação de qualidade. 4. É por esse motivo que, em um primeiro momento, a reserva do possível não pode ser oposta à efetivação dos Direitos Fundamentais, já que, quanto a estes, não cabe ao administrador público preterí-los em suas escolhas. Nem mesmo a vontade da maioria pode tratar tais direitos como secundários. [...] 5. Com isso, observa-se que a realização dos Direitos Fundamentais não é opção do governante, não é resultado de um juízo discricionário nem pode ser encarada como tema que depende unicamente da vontade política. Aqueles direitos que estão intimamente ligados à dignidade humana não podem ser limitados em razão da escassez quando esta é fruto das escolhas do administrador. Não é por outra razão que se afirma que a reserva do possível não é oponível à realização do mínimo existencial. 6 . O mínimo existencial não se resume ao mínimo vital, ou seja, o mínimo para se viver. $\mathrm{O}$ conteúdo daquilo que seja o mínimo existencial abrange também as condições socioculturais, que, para além da questão da mera sobrevivência, asseguram ao indivíduo um mínimo de inserção na "vida" social. 7. Sendo assim, não fica difícil perceber que, dentre os direitos considerados prioritários, encontra-se o direito à educação. O que distingue o homem dos demais seres vivos não é a sua condição de animal social, mas sim de ser um animal político. É a sua capacidade de relacionar-se com os demais e, por meio da ação e do discurso, programar a vida em sociedade. 8. A consciência de que é da essência do ser humano, inclusive sendo o seu traço característico, o relacionamento com os demais em um espaço público - onde todos são, in abstrato, iguais, e cuja diferenciação se dá mais em razão da capacidade para a ação e o discurso do que em virtude de atributos biológicos - é que torna a educação um valor ímpar. No espaço público, em que se travam as relações comerciais, profissionais, trabalhistas, bem como onde se exerce a cidadania, a ausência de educação, de conhecimento, em regra, relega o indivíduo a posições subalternas, o torna dependente das forças físicas para continuar a sobreviver e, ainda assim, em condições precárias. 9. Eis a razão pela qual o art. 227 da CF e o art. $4^{\circ}$ da Lei 8.069/90 dispõem que a educação deve ser tratada pelo Estado com absoluta prioridade. No mesmo sentido, o art. 54 do Estatuto da Criança e do Adolescente prescreve que é dever do Estado assegurar às crianças de zero a seis anos de idade o atendimento em creche e pré-escola. Portanto, o pleito do Ministério Público encontra respaldo legal e jurisprudencial. Precedentes: REsp 511.645/SP, Rel. Min. Herman Benjamin, Segunda Turma, julgado em 18.8.2009, DJe 27.8.2009; RE 410.715 AgR / SP - Rel. Min. Celso de Mello, julgado em 22.11.2005, DJ 3.2.2006, p. 76. 10. Porém, é preciso fazer uma ressalva no sentido de que, mesmo com a alocação dos recursos no atendimento do mínimo existencial, persista a carência orçamentária para atender a todas as demandas. Nesse caso, a 
escassez não seria fruto da escolha de atividades não prioritárias, mas sim da real insuficiência orçamentária. Em situações limítrofes como essa, não há como o Poder Judiciário imiscuir-se nos planos governamentais, pois estes, dentro do que é possível, estão de acordo com a Constituição, não havendo omissão injustificável. 11. Todavia, a real insuficiência de recursos deve ser demonstrada pelo Poder Público, não sendo admitido que a tese seja utilizada como uma desculpa genérica para a omissão estatal no campo da efetivação dos direitos fundamentais, principalmente os de cunho social. No caso dos autos, não houve essa demonstração. Precedente: REsp 764.085/PR, Rel. Min. Humberto Martins, Segunda Turma, julgado em $1^{\circ} .12 .2009$, DJe 10.12.2009. (BRASIL, 2010b, online, grifo nosso).

Ou seja, o Poder Judiciário brasileiro tem entendido que o Estado não pode deixar de assegurar direitos fundamentais à sociedade, em decorrência de opções políticas, ressalvadas as hipóteses em que haja, verdadeiramente, carência orçamentária que resulte na impossibilidade de se realizar tais direitos. Entretanto, situações em concreto não se revelam assim tão simples.

Imagine-se que, em uma determinada comunidade, haja, ao mesmo tempo, a necessidade de construção de um hospital, de um lado, e, de outro, a necessidade de instalação de uma escola de ensino pré-escolar. Inexistindo provisão de fundos suficientes para atender a ambas as demandas, surge um conflito entre o direito fundamental à saúde (art. 196 da Constituição Federal) e o direito fundamental à educação (art. 205 da Constituição Federal). O agente político, nesse caso, será obrigado a tomar uma decisão que, em seu julgamento, atenda melhor aos anseios da sociedade. Em muitas situações, seja qual for a solução (isto é, ainda que seja a melhor, ou a mais justa, ou a que atende ao maior número), é uma opção trágica, que gera o sacrifício daquilo que não foi escolhido (GALDINO, 2005, p. 159).

Considerando-se o fato de que a eventual escassez de recursos pode resultar na impossibilidade de realização simultânea e extensiva de todos os direitos sociais, de modo que alguns devam ser priorizados em detrimento de outros, resta o impasse de como o Estado deve atuar com o fim de proporcionar à sociedade a efetividade dos direitos fundamentais sociais.

Conforme se infere de dados divulgados pelo Instituto Brasileiro de Geografia e Estatística (IBGE), houve uma expansão significativa na estrutura de ensino pré-escolar no Município de Belo Horizonte, entre os anos de 2005 e 2015:

\begin{tabular}{c|c|c|c}
\hline \multicolumn{4}{c}{$\begin{array}{c}\text { DADOS ESTATÍSTICOS } \\
\text { PRÉ-ESCOLA EM BELO HORIZONTE/MG } \\
\text { (Crianças de 0 a 5 anos de idade) }\end{array}$} \\
\hline Ano & N. de Matrículas & N. de Docentes & N. de Escolas \\
\hline 2005 & 10.874 & 801 & 67 \\
2009 & 15.212 & 997 & 78 \\
2012 & 14.900 & 948 & 89 \\
2015 & 17.558 & 1.312 & 131 \\
\hline
\end{tabular}

Quadro 1 - Dados estatísticos pré-escola em Belo Horizonte/MG Fonte: (IBGE, 2017). 
Os investimentos realizados, entretanto, não foram suficientes para suprir a demanda social, algo que pode ser facilmente averiguado pelo crescente número de processos judiciais ajuizados por pais insatisfeitos com a impossibilidade de matricular seus filhos menores de cinco anos na pré-escola.

O contexto narrado, portanto, apresenta fortes evidências de que a política pública adotada pelo Município de Belo Horizonte para garantir acesso de todos ao ensino básico de qualidade não está sendo suficiente para alcançar os objetivos almejados, pelo que se mostra pertinente a adoção de outras medidas, complementares àquelas que vêm sendo implementadas, que possam contribuir para o atendimento dos legítimos anseios sociais, assegurados pela Constituição Federal como direitos subjetivos e não meramente como expectativas. A premência de se utilizar de outros meios para se concretizar o mencionado fim revela-se ainda mais urgente, tendo em vista os prejuízos que podem advir da intervenção do Poder Judiciário nas políticas públicas, como no caso em análise.

\section{PLANEJAMENTO E POLÍTICAS PÚBLICAS COMO MEIOS DE CON- CRETIZAÇÃO DO DIREITO FUNDAMENTAL DE ACESSO AO ENSINO INFANTIL DE BOA QUALIDADE}

De acordo com Washington Peluso Albino de Souza, o planejamento, pode, sucintamente, ser definido como "uma "técnica" de intervenção do Estado no domínio econômico." (SOUZA, 2005, p. 371). Mas, para o autor, é necessário realizar uma diferenciação entre "planejamento" e "plano":

O primeiro, que em certos idiomas se denomina apenas "Planificação", constitui o "ato de planejar", e prende-se essencialmente à ideia de racionalizar o emprego de meios disponíveis para deles retirar os efeitos mais favoráveis. Seu conceito está intimamente ligado ao sentido do que seja o "econômico", visto como este traduz o intuito de obter a "maior vantagem" do emprego de meios escassos, para a sua consecução. Levada adiante a ideia da "planificação" como "ação de planejar", poderemos esmiuçar mais o sentido do termo "Planejamento" e atribuir-lhe ligação íntima com a adoção de "planificação", isto é, a "determinação" (já de natureza política) de se aplicar a "planificação" como método de intervir, ou seja, de concretizar a intervenção do Estado no domínio econômico. Neste caso, "plano" é o documento, a "peça técnica" decorrente da "ação de planejar", da "planificação", quando se adota a orientação político-econômica de "intervenção" pelo "Planejamento". (SOUZA, 2005, p. 372).

Por intermédio do planejamento, a Administração Pública busca obter maior vantagem no emprego dos recursos escassos. Para tanto, traça-se o caminho que deve ser percorrido, pela adoção de medidas coordenadas que culminarão no alcance eficiente de determinada finalidade.

A materialização do planejamento, por parte do Estado, dá-se mediante a adoção de políticas públicas, direcionadas ao alcance da finalidade almejada. As Políticas Públicas podem ser definidas como: 
[...] um conjunto de decisões inter-relacionadas, tomadas por um ator ou grupo de atores políticos, e que dizem respeito à seleção de objetivos e dos meios necessários para alcançá-los, dentro de uma situação específica em que o alvo dessas decisões estaria, em princípio, ao alcance desses atores. (JENKINS apud HOWLETT; RAMESH; PERL, 2013, p. 8).

Esse processo de compatibilização de objetivos e meios tem duas dimensões, sendo elas a "técnica" e a "política". A dimensão técnica, de caráter mais científico-objetiva, procura identificar a relação ótima entre objetivos e instrumentos, considerando-se que alguns instrumentos são mais adequados do que outros na solução ou minimização de problemas. A segunda dimensão, de natureza política, reside no fato de que nem todos os atores estão de acordo com o que constitui um problema político, apto a ser solucionado por uma política pública (HOWLETT; RAMESH; PERL, 2013, p. 6).

Portanto, para que uma política pública seja efetivamente adotada e implementada, não basta que, sob o ponto de vista técnico, ela seja adequada. Para que isso ocorra, é necessário que os agentes políticos, responsáveis pela tomada de decisão em nome do Estado, decidam nesse sentido. $O$ que muitas vezes acontece nessa seara são embates ideológicos entre os agentes políticos, que, em vez de efetivamente se utilizarem de medidas tecnicamente adequadas, acabam optando por outros meios menos apropriados do ponto de vista do plano, que, em tese, garantiriam a eficiência do planejamento.

Para fins analíticos, a política pública pode ser vista como um processo, composto pelos seguintes estágios:

a) montagem da agenda;

b) formulação de políticas;

c) tomada de decisão política;

d) implementação de políticas;

e) avaliação de políticas e;

f) manutenção, revisão ou cancelamento da política pública.

Esse modelo, apesar de não ser absoluto, auxilia o desdobramento do processo político-administrativo em uma série de estágios distintos, dotados de maior complexidade (HOWLETT; RAMESH; PERL, 2013, p. 16).

Destaca-se, pela especificidade do tema abordado neste artigo, que a política pública realizada em âmbito local tem ainda especial relevância para a população que é imediatamente interessada em solucionar um problema cotidianamente vivenciado. A inacessibilidade ao ensino infantil de boa qualidade, característica marcante no Brasil, tem sido amenizada em Belo Horizonte por intermédio das UMEIs. Ao tratar do tema de políticas públicas no nível municipal da Federação, Calgaro e Pereira assentuam a afirmação da autonomia dos munícipes para tratar de seus problemas:

As políticas públicas no espaço local são importantes para que a sociedade possa solver seus problemas de forma mais harmônica e consensual, visto que os indivíduos conhecem bem seus problemas. Dessa forma, quando se analisa o espaço local, percebe-se que vai proporcionar autonomia à população, permitin- 
do que os cidadãos possam participar da tomada de decisões em seu Município (CALGARO; PEREIRA, 2017, p. 291).

Tendo em vista que o presente estudo não objetiva analisar de forma pormenorizada os procedimentos e elementos que compõem a formulação de políticas públicas, mas tão somente sugerir meios capazes de contribuir para a solução de um problema corrente no Município de Belo Horizonte (universalização do ensino infantil de qualidade), buscar-se-á demonstrar as questões relacionadas à inclusão da matéria na agenda do Município, bem como apresentar uma proposta para formulação de política pública apta a contribuir para a solução do problema.

\subsection{MONTAGEM DA AGENDA}

John Kingdon, de acordo com Howett, Ramesh e Perl, em pesquisa datada de 1984 sobre os estágios do ciclo de políticas públicas nos Estados Unidos, define a agenda como

[...] a lista das questões ou problemas que recebem alguma atenção séria, em algum dado momento, por parte dos funcionários do governo e das pessoas de fora do governo que estão próximas a estes funcionários... Do conjunto de todas as questões ou problemas concebíveis, aos quais os funcionários poderiam estar voltando sua atenção, na realidade prestam séria atenção apenas a alguns, e não a outros. Assim, o processo da montagem da agenda limita esse conjunto de questões concebíveis ao conjunto que de fato se torna foco de atenção (KINGDON apud HOWLETT; RAMESH; PERL, 2013, p. 103).

Ou seja, a formulação da agenda trata do procedimento de identificação, por parte dos agentes políticos, dos problemas que demandam atenção do Estado. Ainda de acordo com mencionados autores, Cobb e Elder fizeram uma distinção entre a agenda pública sistêmica (ou informal) e a agenda de Estado, institucional ou formal. A primeira é composta pelas matérias que, de acordo com a opinião geral dos agentes políticos, merece atenção do Estado. Nesse caso, nenhuma medida é tomada, apesar da identificação do problema. A agenda formal, por seu turno, consiste não apenas na identificação do problema por parte dos agentes políticos, mas sua efetiva inclusão na pauta institucional do governo. Em outras palavras, a agenda pública é voltada à discussão, enquanto a institucional, à ação (HOWLETT; RAMESH; PERL, 2013, p. 113).

No caso em apreço, a questão relacionada à falta de vagas para crianças de zero a cinco anos em escolas municipais de qualidade tem, certamente, causado transtornos à Administração Pública. Isso ocorre porque, em virtude da ausência de vagas em boas escolas infantis, reiteradas decisões judiciais têm sido proferidas para compelir a municipalidade a oferecer vagas nas denominadas Unidades Municipais de Educação Infantil (UMEIs), em quantidade muito superior àquelas efetivamente disponíveis. $\mathrm{O}$ assunto, por conseguinte, é objeto de discussões pelos agentes integrantes do Município com a sociedade, e, logo, pode-se considerar incluído na pauta da agenda informal. 
Ao mesmo tempo, por meio dos dados colacionados anteriormente, referentes à estrutura de pré-escolas no Município de Belo Horizonte, percebe-se que houve, nos últimos anos (compreendidos entre 2005 e 2015), uma verdadeira expansão do sistema de ensino infantil, com a abertura de novas escolas (o número de instituições saltou de 67 para 131), acompanhada da contratação de novos professores (o número de docentes passou de 801 para 1.312) e do acréscimo no número de matrículas (o número de alunos elevou-se de 10.874 para 17.558). Esses dados sugerem que a questão está oficialmente incluída na agenda de políticas públicas educacionais do Município, pois este está visivelmente investindo na expansão do seu sistema de educação infantil.

Entretanto, conforme já afirmado anteriormente, as políticas públicas adotadas pelo Município aparentemente não estão surtindo os efeitos necessários ao efetivo atendimento das necessidades sociais. $\mathrm{O}$ enorme contingente judicial citado neste estudo, que decorre da insatisfação dos pais que não conseguem vaga para seus filhos em instituição municipal, é um forte indício disto.

Nesse sentido, mostra-se pertinente a análise acerca de eventuais medidas que poderiam ser tomadas no intuito de se formular novas políticas públicas capazes de contribuir para a solução desse problema enfrentado pelo Município de Belo Horizonte.

\subsection{INSTRUMENTOS PARA FORMULAÇÃO DE POLÍTICAS PÚBLICAS}

De acordo com Howett, Ramesh e Perl (2013, p. 123), "a formulação da política pública refere-se ao processo de criação de opções sobre o que fazer a respeito de um determinado problema público." Nessa etapa do processo, "faz-se a identificação, o refinamento e a formalização das opções políticas que poderão resolver as questões e os problemas reconhecidos no estágio de montagem da agenda." (HOWLETT; RAMESH; PERL, 2013, p. 123).

A formulação da política pública deverá levar em consideração, portanto, as restrições que o Estado enfrenta para alcançar o seu objetivo. Essas limitações podem ser classificadas como procedimentais ou substantivas. A primeira ordem de restrições está relacionada à forma de proceder no intuito de solucionar determinado problema. Isso, pois, certas ações podem ser vedadas ou inacessíveis ao Estado, em decorrência de estruturação governamental, sistemas políticos, legislação, dentre outros. Quanto às limitações substantivas, ensinam Howett, Ramesh e Perl:

As restrições substantivas são inerentes à natureza do próprio problema. Assim, os policy-makers que desejam eliminar a pobreza não têm a opção de imprimir moeda e distribuí-la aos pobres, porque a inflação compensaria todos os ganhos e, por isso, têm que, necessariamente, enfrentar o problema de maneira mais indireta. De modo similar, o objetivo de promover excelência nas artes ou nos esportes não será alcançado simplesmente com a ordem de que as pessoas sejam os melhores artistas ou esportistas do mundo; a perseguição desses objetivos requer medidas muito mais delicadas, dispendiosas e consumidoras de tempo. [...] 
Os problemas substantivos são, portanto, "objetivos", no sentido de que sua redefinição não os faz desaparecer, e sua resolução total ou parcial requer o uso de recursos e capacidades do Estado, como dinheiro, informação, pessoal e/ou o exercício da autoridade estatal (HOWLETT; RAMESH; PERL, 2013, p. 126) .

No caso do Município de Belo Horizonte, tem-se percebido um indício de restrição substantiva, no que tange à criação de vagas em escolas infantis suficientes para suprir a demanda da sociedade. Não obstante os progressivos aumentos de investimentos que vêm sendo realizados no setor da educação infantil, inclusive por meio de Parceria PúblicoPrivada, o volume de ações judiciais continua crescendo em face da municipalidade, que se obriga, de modo reiterado, a cumprir ordens judicias que não estavam incluídas em seu planejamento fiscal-orçamentário-operacional. Uma maneira mais indireta de enfrentamento do problema, conforme sugerem Howett, Ramesh e Perl, poderia contribuir para o alcance de uma solução.

Conforme já dito, as opções que serão apresentadas como possibilidades de políticas públicas deverão se basear não apenas nos fundamentos tecnicamente aceitáveis para a solução ou minimização do problema, mas, também, naquilo que se acredita ser politicamente aceitável e, ainda, financeira e administrativamente viável. Diante das inúmeras variáveis que podem surgir a partir desses elementos, os agentes políticos, mesmo que identifiquem conjuntamente a existência de determinado problema, podem discordar acerca das medidas que devam ser tomadas para se alcançar uma solução.

No estágio da formulação, portanto, serão realizadas propostas por parte dos agentes políticos, para escolha das ações que serão direcionadas à solução de determinado problema incluído na agenda. Nessa etapa, além do diagnóstico do problema (já feito na fase anterior), são sugeridos prognósticos para a solução ou a minimização do problema (CUSTÓDIO; OLIVEIRA, 2015). Assim, e apesar de os instrumentos disponíveis para adoção destas ações serem ilimitados, Christopher Hood (apud HOWLETT; RAMESH; PERL, 2013, p. 128) desenvolveu uma taxonomia bastante útil, conhecida como "modelo NATO", propondo que os instrumentos políticos para solução de problemas se enquadrariam em quatro categorias, sendo:

a) nodalidade (uso de informações do governo);

b) autoridade;

c) tesouro e;

d) organização.

O esquema de classificação que segue, extraído da obra de Howett, Ramesh e Perl (2013, p. 130), cita alguns exemplos de instrumentos encontrados dentro de cada categoria: 


\begin{tabular}{c|c|c|c}
\hline Nodalidade & Autoridade & Tesouro & Organização \\
\hline $\begin{array}{c}\text { Coleta e liberação } \\
\text { de informação }\end{array}$ & $\begin{array}{c}\text { Regulação de } \\
\text { comando e controle }\end{array}$ & $\begin{array}{c}\text { Verbas e } \\
\text { empréstimos }\end{array}$ & $\begin{array}{c}\text { Provisão direta de } \\
\text { bens e serviços e } \\
\text { empresas públicas }\end{array}$ \\
\hline Assessoria e exortação & Autorregulação & Taxas de uso & $\begin{array}{c}\text { Recurso à família, à } \\
\text { comunidade e a orga- } \\
\text { nizações voluntárias }\end{array}$ \\
\hline $\begin{array}{c}\text { Comissões e } \\
\text { investigações }\end{array}$ & $\begin{array}{c}\text { Fixação de padrão e } \\
\text { regulação delegada }\end{array}$ & $\begin{array}{c}\text { Impostos e dispên- } \\
\text { dios de impostos }\end{array}$ & Criação de mercado \\
\hline e consultorias & $\begin{array}{c}\text { Criação e financia- } \\
\text { mento de grupos de } \\
\text { interesse }\end{array}$ & $\begin{array}{c}\text { Reorganização } \\
\text { governamental }\end{array}$ \\
\hline
\end{tabular}

Quadro 2 - Esquema de classificação

Fonte: Howett, Ramesh e Perl (2013, p. 130).

A formulação de políticas públicas, portanto, implica a seleção das ferramentas que serão potencialmente aptas a solucionar determinado problema político. Considerando que, para solucionar um problema, o Estado pode e, muitas vezes, deve adotar mais de um campo de ação, não se sugerirá, aqui, que o Município de Belo Horizonte deixe de realizar investimentos na expansão do sistema de ensino, por meio de Parceria Público-Privada, na forma como já se tem feito. O que se buscará, por meio deste estudo, é demonstrar a possibilidade de adoção de novas ferramentas aptas a contribuir com a política pública já em andamento.

Tendo em vista que o objetivo deste estudo não é o de discorrer acerca das ferramentas enquadradas dentro de cada uma das categorias do "modelo NATO", sugerirá três instrumentos a serem utilizados, na tentativa de se contribuir para a solução enfrentada pelo Município de Belo Horizonte, sendo eles:

a) na categoria tesouro, a utilização de verbas direcionadas à sociedade;

b) na categoria autoridade, a utilização da regulação de comando e controle e;

c) na categoria nodalidade, a coleta e liberação de informação.

Adiante, este estudo buscará aprofundar-se no âmbito dos instrumentos acima elencados, para, na categoria tesouro, propor a utilização de vouchers como instrumento complementar às políticas públicas já implementadas; na categoria autoridade, utilizar de seu poder fiscalizatório para averiguar a regularidade na utilização da política proposta; e, na categoria nodalidade, criar programas de conscientização dos pais, acerca da importância da participação ativa no aprendizado dos filhos.

\subsection{DA PROPOSTA DE FORMULAÇÃO DE POLÍTICA PÚBLICA}

Atualmente, os critérios de seleção para o ingresso nas UMEIs, especificamente para crianças de zero a três anos, são os seguintes: a) a matrícula é compulsória para crianças com 
deficiência ou sob medida protetiva; e b) do restante das vagas: 70\% são preenchidas, por ordem de classificação, pelas crianças pertencentes a famílias em situação de vulnerabilidade social; $10 \%$ das vagas são preenchidas por meio de sorteio entre as famílias cujo endereço de residência ou do trabalho dos pais esteja no raio de até um quilômetro da unidade e 20\% são preenchidas por sorteio público, no qual participarão todas as crianças não incluídas nos critérios anteriores (BELO HORIZONTE, 2015).

Conforme se percebe, o Município de Belo Horizonte, ao estabelecer os critérios de seleção para o ingresso nas escolas infantis, já incluiu a hipótese de as crianças estarem sob medidas protetivas, ou seja, os agentes públicos estão a reconhecer, formalmente, a possibilidade de haver crianças resguardadas por decisões judiciais. Desse modo, embora os demais critérios eleitos para seleção das vagas sejam coerentes, por privilegiarem as crianças com deficiência, as famílias menos favorecidas e aquelas que vivem nos arredores de cada instituição, estes acabam sendo prejudicados, por força das ações judiciais ajuizadas por pais de crianças que não se enquadram nos critérios fixados.

Considerando que as famílias com poderio econômico social reduzido não têm acesso, muitas vezes, a um advogado, o problema se mostra ainda mais grave, pois os reais necessitados de um ensino público gratuito perdem a prioridade da sua admissão nas UMEIs, em favor de famílias que, muitas vezes, teriam condições de arcar com um ensino privado de qualidade. ${ }^{6}$

Nesse sentido, até que houvesse um número suficiente de vagas em UMEIs, capazes de atender a toda a sociedade, com o desenvolvimento da política de Parceria Público-Privada já implantada, o Município poderia adotar outros mecanismos que contribuíssem para a universalização do ensino infantil gratuito e de qualidade.

Antes de se abordar, a título de exemplicação, duas propostas de políticas públicas de acessibilidade ao ensino fundamental, frisa-se que a Constituição, em seu artigo 208, inciso IV, estabelece que o Estado tem o dever não de prestar, por si mesmo, o serviço escolar às crianças de até cinco anos, mas o dever de garantir a educação infantil. Ao mesmo tempo, a Constituição dispõe, em seu artigo 209, que o ensino é livre à iniciativa privada, desde que cumpridas as normas gerais aplicáveis e, ainda, que as instituições sejam avaliadas e autorizadas pelo Poder Público a funcionar.

Dito isso, convida-se o leitor a refletir a respeito de algumas possibilidades para se desenvolver a sinergia entre os entes públicos e privados, de forma a criar um sistema colaborativo que funcionaria em prol tanto da coletividade quanto do indivíduo. Ressalta-se que este estudo não tem o condão de defender doutrinas ou convicções político-ideológicas ou político-partidárias, mas tão somente buscar contribuir para o debate acerca de métodos de universalização do acesso ao ensino infantil de qualidade como elementos de política pública, ainda que transitórias.

Uma proposta que representa verdadeiro tabu ideológico, com relação à universalização do ensino, é aquela consistente no denominado sistema de vouchers, sugerida pelo economista norte-americano Milton Friedman, vencedor do Prêmio Nobel de Economia em 1976. De 
acordo com o sistema originalmente proposto, o Estado seria responsável por arcar integralmente com todos os custos decorrentes da educação, por meio de subsídios fornecidos aos pais das crianças, que, por sua vez, seriam os responsáveis por escolher alguma instituição privada para matricular os seus filhos (FRIEDMAN, 1977).

Nesse cenário, os pais receberiam os vouchers do Estado e os utilizariam para pagar a escola privada em que seus filhos estivessem matriculados. A instituição de ensino, por seu turno, poderia trocar esses vouchers por dinheiro, junto ao Estado. Os vouchers seriam, desse modo, como "cartas de crédito". Argumenta-se que, nos moldes do sistema sugerido, os pais, por terem o poder de escolha com relação a qual instituição de ensino irão escolher para seus filhos, seja ela pública, seja privada, tenderiam a optar por aquilo que fosse do melhor interesse das crianças (FRIEDMAN, 1977).

No Brasil, entretanto, não existe consenso a respeito da adoção desse sistema. Para parte da doutrina, o acesso universal à educação é, por princípio, um dever do Estado, o que excluiria a atuação privada nesse setor. Antonio Ibañez Ruiz, ex-secretário Nacional de Educação Profissional e Tecnológica do Ministério da Educação (2003 a 2005), na presidência de Luiz Inácio Lula da Silva, afirma que o sistema de vouchers seria, inclusive, inconstitucional, exatamente sob o argumento de que a prestação do serviço de ensino seria uma obrigação do próprio Estado (LOPES, 2003).

Há, também, pensadores adeptos do modelo liberal que não concordam com a proposta sob análise. Para estes, a adoção de vouchers resultaria em um efeito nefasto sobre o sistema de ensino privado, pois este se tornaria refém do Estado e da burocracia, que teriam controle sobre os pagamentos devidos (ROCKWELL, 2014). As escolas privadas, portanto, tenderiam a se tornar públicas e perder qualidade. Paulo Renato Souza, ex-ministro da Educação na presidência de Fernando Henrique Cardoso (1995-2003), argumentou, em entrevista, que a ideia dos vouchers não funcionaria e que o problema das escolas públicas ruins decorreria, geralmente, da falha de gestão (LOPES, 2003).

Os conflitos de ideias que pairam ao redor do tema, portanto, tornam bastante delicadas as eventuais decisões políticas tomadas no sentido de adotar o sistema de vouchers na escola. Entretanto, se se considerasse que o interesse fundamentado em ambas as vertentes de pensamento residiria na universalização e na qualidade do ensino, uma reflexão mais aprofundada a respeito do tema, buscando-se se apegar apenas aos pontos positivos de cada uma, mostra-se academicamente apropriada.

Com relação às críticas direcionadas à possibilidade de declínio da qualidade do ensino, em decorrência do sistema de vouchers, algumas medidas poderiam ser tomadas, no intuito de mitigar eventuais riscos. Conforme descrito na própria Constituição Federal, em seu artigo 209, existem determinadas condições a serem estabelecidas em lei que devem ser preenchidas para que uma instituição de ensino privado funcione no Brasil; condições que devem ser fiscalizadas permanentemente pelo governo, com o auxílio da sociedade. Ademais, outros requisitos poderiam ser instituídos para aquelas escolas que recebam alunos beneficiados pelo 
sistema proposto, como limite máximo de alunos por turma, limite mínimo de professores para determinada quantidade de alunos, limite mínimo de salas de aulas em cada escola em relação ao número de alunos, exigência de contratação mínima de professores com uma determinada certificação, dentre outras.

Quanto à qualidade do sistema de ensino, campanhas de conscientização poderiam ser lançadas para cientificar os pais dos alunos acerca da importância de se acompanhar os filhos na escola. Isso contribuiria para a geração de um sistema sustentável, em que os pais, munidos de conhecimento e incentivo conferidos pelo Estado, auxiliariam na fiscalização do sistema de ensino no qual seus filhos estariam inseridos. Além do mais, caso as escolas privadas começassem a decair no nível de qualidade, os pais teriam sempre a prerrogativa de escolher uma nova escola para seus filhos, alternativa que, no sistema de escolas públicas, muitas vezes, não seria possível. Nesse caso, a eventual concorrência por boas escolas tenderia a manter a qualidade do ensino por elas oferecido. Ainda com relação à importância de conscientização dos pais acerca do método proposto, esclarecedora a posição de Soo-Hyang Choi (2004, p. 23): “A vantagem da alternativa 'apoio aos pais' é que ela confere liberdade aos pais de escolherem o que é melhor para seus filhos. Mas se a escolha dos pais não for adequadamente orientada, pode-se ter como conseqüência o mau uso do apoio governamental.”

A respeito da crítica consistente em eventual engessamento, pela burocracia estatal, do sistema de ensino privado, uma alternativa ao modelo de vouchers se apresenta como subsídio indireto da educação: em vez dos vouchers, os pais das crianças receberiam dinheiro do Estado, para custear o ensino de seus filhos.

Tanto o modelo de concessão de vouchers quanto o da entrega de dinheiro aos país dos alunos poderiam ser medidas transitórias até que o ente estatal consiga universalizar o acesso ao ensino público. Mas poderiam, ainda, se tornarem medidas acessórias a título alternativo para determinadas situações a serem debatidas com a sociedade.

No Brasil, os governos federais dos últimos 20 anos adotaram políticas públicas que, guardadas as particularidades, se assemelham àquelas que foram acima analisadas.

A título de ilustração, o Governo Federal, sob o Partido dos Trabalhadores (2003 a 2016), instituiu o programa denominado Bolsa Família, destinado a combater a pobreza e a desigualdade social no país. Por meio desse programa, ainda em vigor, os indivíduos que comprovarem, mediante preenchimento de determinados requisitos, a condição de pobreza, recebem uma complementação mensal de renda. Em igual sentido, e, no caso do subsídio indireto escolar que ora se analisa, os pais das crianças, para receberem o benefício, teriam de demonstrar, por exemplo, ter filhos de até determinada idade e, ainda, a matrícula e o acompanhamento escolar destes.

Conforme disposição da Lei n. 10.836, de 2004 (art. 1º Parágrafo único) (BRASIL, 2004), o Bolsa Família é resultado da unificação de programas anteriores, denominados Bolsa Escola, Programa Nacional de Acesso à Alimentação (PNAA), Bolsa Alimentação e Programa Auxílio-Gás. O Bolsa Família, entretanto, descomplicou o sistema, ao consolidar 
o benefício em um simples repasse de fundos aos indivíduos em situação de pobreza, que, à sua própria discrição, podem utilizá-los para seu sustento. Por meio desse programa de promoção da equidade socioeconômica, a União, em parceria com os Estados-Membros, Distrito Federal e Municipios, em doze anos de trabalho, conseguiu retirar 36 milhões de pessoas da pobreza extrema, conforme se infere do sítio eletrônico do Portal Brasil (BRASIL, 2015).

O que se verifica, portanto, no caso de auxílio direto à eduação (quer por meio de concessão de vouchers ou da entrega de valor monetário em espécie), é descomplicar o sistema de acesso universal ao ensino - no caso, o da municipalidade de Belo Horizonte -, permitindo-se aos pais das crianças que recebam fundos do ente estal que os habilite escolher as escolas que julgarem ser mais adequadas para os seus filhos, quer a título transitório ou até permanente em algumas situações. Isso reduziria o efeito negativo do excesso das demandas judiciais e da inadequada realização indireta de política pública pelo Poder Judiciário.

Concomitantemente, a adoação de medida dessa natureza poderia ter o efeito positivo de reduzir encargos estatais com a manutenção ou a ampliação do aparelho governamental, sem o adequado planejamento. Certo, porém, é que, nesse contexto, a função fiscalizadora do Estado quanto à observância das regras de qualidade da prestação do serviço de educação, pela iniciativa privada, deve ser aprimorada.

Sem embargo das inúmeras críticas que são realizadas a esse sistema, importante reparar que o Município de Belo Horizonte, ao adotar a política de Parceria Público-Privada na criação das UMEIs, vem conseguindo alcançar um alto nível de qualidade na prestação do serviço de educação infantil, com avanços significativos na sua universalização. A crescente quantidade de demandas judiciais visando ao acesso a esse tipo de ensino tem sido fundamentada pelo reconhecimento dessa qualidade por parte da sociedade e das insituições estatais (Ministério Público, Defensoria Pública, Advocacia Pública e Poder Judiciário). O exemplo de Parceria Público-Privado adotado no sistema das UMEIs vem demonstrando que os entes privados e estatais podem trabalhar lado a lado, em sinergia, de forma a gerar eficiência administrativa na boa prestação de serviços públicos para a sociedade.

Não se defende, neste estudo, e sob nenhum argumento constitucionalmente plausível, a extinção da rede pública de ensino infantil, mas tão somente uma política pública complementar, que contribua para a universalização do ensino infantil de qualidade. Assim, o Município poderia, temporariamente, conferir aos pais de alunos que não conseguissem as almejadas vagas nas UMEIs, a alternativa de receber, mensalmente, o subsídio indireto para educação de seus filhos. Apenas os pais que não aceitassem essa alternativa recorreriam ao Poder Judiciário, algo que, por si só, já contribuiria para a diminuição do contingente judicial e, principalmente, para uma maior satisfação dos interesses sociais na busca pela universalização do direito ao ensino com qualidade. 


\section{CONCLUSÃO}

Conforme demonstrado ao longo deste estudo, o direito fundamental à educação é oponível ao Estado e deve, portanto, ser prestado a todos. Considerando que esse direito tem natureza prestacional primária, a sua concretização depende de marcos regulatórios e de adoção de políticas públicas bem planejadas, sob pena de ineficiência quanto à garantia de sua acessibilidade universal e de sua qualidade.

No caso em estudo, o Município de Belo Horizonte, por meio de Parceria Público-Privada, instituiu o sistema de educação básica realizado nas Unidades Municipais de Educação Infantil (UMEIs), para crianças entre zero e cinco anos de idade. $\mathrm{O}$ referido sistema, que vem sendo progressivamente ampliado em sua acessibilidade, tem revelado alta qualidade na prestação do serviço de educação infantil.

Entretanto, o sistema ainda não consegue suprir toda a demanda da sociedade, observados os critérios para nele ingressar. Por conseguinte, a municipalidade vem sendo ré em diversas ações judiciais que pleiteiam o acesso às UMEIs, com ganho de causa para os pais e outros responsáveis legais. Contudo, a excessiva judicialização tem comprometido o planejamento fiscal, contábel e operacional do Município. Nesse sentido, discute-se, neste trabalho, alternativas de políticas públicas, além da simples expansão direta do sistema de ensino, que poderiam ser adotadas, de modo temporário ou até permanente, no intuito de contribuir para minimizar o problema de acesso ao ensino infantil de qualidade.

Uma forma de contribuir para a solução ou minimização do problema seria a criação de um programa de subsídio indireto da escola, em que os pais de alunos que preenchessem determinados requisitos receberiam, mensalmente, um valor em dinheiro, a ser direcionado ao custeio do ensino de seus filhos em instituições privadas. Concomitamente, o Município teria tempo e condições para planejar e implementar, de modo sustentavél, a expansão do seu sistema de ensino infantil. Ademais, a municipalidade aprimoraria os meios de fiscalização das escolas privadas onde os pais tivessem matriculado os seus filhos e propiciaria a realização de políticas públicas de conscientização dos pais na verificação da qualidade do ensino oferecido em tais escolas.

Assim, a hipótese apresentada na introdução como medida transitória ou permanente - a concessão de subsídio para o custeio da educação infantil - fica confirmada. Essa iniciativa poderia ser instrumento de política pública transitória ou permanente para que a municipalidade pudesse estender o acesso à educação ou pelo menos até que tivesse tempo e condições financeiro-administrativas para viabilizar a criação de novas escolas ou de novas vagas nas UMEIs, de modo planejado e sustentável.

Essa alternativa, que criaria uma relação sinérgica entre os agentes públicos e privados, poderia, ao menos, favorecer a redução do contingente processual contra o Município, de modo a viabilizar a expansão planejada e sustentável do sistema de ensino infantil, por meio de Parceria Público-Privada, conforme já vem sendo feito de modo satisfatório no quesito da qualidade do serviço prestado. 


\title{
PUBLIC POLICY AND THE RIGHT TO GOOD QUALITY CHILDHOOD EDUCATION: THE SITUATION OF UMEIs IN THE MUNICIPALITY OF BELO HORIZONTE
}

\begin{abstract}
The article focuses on the difficulty faced by the municipality of Belo Horizonte - State of Minas Gerais, Brazil - to ensure universal access to quality childhood education in its UMEIs - Municipal Infant Education Units, which has caused a great deal of lawsuits against the municipality, rendering the proper administrative management of the matter unfeasible. It is in this context that the study suggests adopting "school subsidy" as a complementary public policy to solve or reduce the negative effects of the situation, on a transitional or permanent basis. An analytical-descriptive methodology was used in the paper, with the support of legal dogmatic methods and the presentation of statistical data, as well as reference to legislation, case-law and legal studies. Universal access to good quality childhood education as a fundamental right and human right to be provided by the State, with the collaboration of the private sector, is the structuring theoretical framework on which the article is built. From such point, the paper addresses the issue of costs for the implementation of educational entitlements and the need for public policies that extend good childhood schools in a sustainable way.

Keywords: Childhood education. Elementary school. Right to Education. Universalization of the Right to Education. Public policies in education.

\section{POLÍTICA PÚBLICA Y DERECHO A LA EDUCACIÓN INFANTIL DE BUENA CALIDAD: LA SITUACIÓN DE LAS UMEIs EN LA MUNICIPALIDAD DE BELO HORIZONTE}

\section{RESUMEN}

El tema del artículo se centra en la dificultad de la municipalidad de Belo Horizonte - estado de Minas Gerais, Brasil - en asegurar la universalización del acceso a la enseñanza infantil de calidad en sus Unidades Municipales de Educación Infantil (UMEIs), lo que ha causado grande volumen de acciones judiciales contra la municipalidad, lo que inviabiliza la adecuada gestión administrativa de la cuestión. En ese contexto, el estudio sugiere la adopción del "subsidio escolar" como política pública complementar, a título transitorio o permanente, para solucionar o reducir los efectos negativos de la situación. En la elaboración del artículo, se utilizó la metodología analítico-descriptiva del problema fático-jurídico, con el apoyo de métodos jurídicodogmáticos y con la presentación de datos estadísticos, además de la consulta a la legislación, a la jurisprudencia y a la doctrina. El artículo tiene como marco teórico estructurante el acceso universal a la enseñanza infantil de buena calidad como derecho fundamental y derecho 
humano a ser viabilizado por el Estado, con la colaboración de la iniciativa privada. A partir del marco teórico, se aborda la cuestión de los costos para la implementación de los derechos prestacionales primarios y de la necesidad de adopción de políticas públicas que contribuyan, de modo sustentable, para la ampliación del acceso a las escuelas infantiles de calidad.

Palabras-clave: Enseñanza infantil. Enseñanza fundamental. Derecho a la educación. Derechos prestacionales primarios. Universalización del derecho a la educación. Políticas públicas en educación.

1 Declaração Universal dos Direitos Humanos: [...] Artigo XXVI, §1. Toda pessoa tem direito à instrução. A instrução será gratuita, pelo menos nos graus elementares e fundamentais. A instrução elementar será obrigatória. A instrução técnico-profissional será acessível a todos, bem como a instrução superior, está baseada no mérito. §2. A instrução será orientada no sentido do pleno desenvolvimento da personalidade humana e do fortalecimento do respeito pelos direitos humanos e pelas liberdades fundamentais. A instrução promoverá a compreensão, a tolerância e a amizade entre todas as nações e grupos raciais ou religiosos, e coadjuvará as atividades das Nações Unidas em prol da manutenção da paz. §3. Os pais têm prioridade de direito na escolha do gênero de instrução que será ministrada a seus filhos. (OHCHR, 1948).

2 Convenção para a Prevenção e a Repressão do Crime de Genocídio (1948), Convenção Internacional sobre a Eliminação de Todas as Formas de Discriminação Racial (1965), Convenção sobre a Eliminação de Todas as Formas de Discriminação contra as Mulheres (1979), Convenção sobre os Direitos da Criança (1989), dentre outras.

3 O serviço experimental começou em 1972 para crianças (desde bebês até 5 anos) de famílias de baixa renda. O estudo de impacto acompanhou 112 crianças do projeto e mediu seu desenvolvimento e realizações em diferentes idades dos 8 aos 21 anos.

4 À época em que as decisões foram tomadas, o Estatuto da Criança e do Adolescente determinava que o atendimento em creche e pré-escola era obrigatório às crianças de até seis anos de idade. O diploma legal foi alterado, todavia, pela Lei no 13.306, de 4 de julho de 2016, passando a garantir o ensino infantil às crianças de até cinco anos de idade.

5 Alguns precedentes do Tribunal de Justiça de Minas Gerais: 1.0024.06.929596-2/002; 1.0024.11.3078273/001; 1.0145.13.066969-3/001; 1.0145.14.020363-2/001; 1.0521.13.006996-1/002; 1.0024.04.407745-1/001; 1.0024.09.737176-9/002; 1.0024.11.044187-0/002; 1.0024.11.062949-0/002; 1.0024.12.132139-2/002; $1.0024 .12 .227871-6 / 001 ; 1.0024 .13 .169718-7 / 002 ; 1.0105 .11 .029460-7 / 002 ; 1.0105 .13 .005380-1 / 001$; $1.0145 .13 .060374-2 / 003 ; 1.0151 .10 .003366-2 / 001 ; 1.0194 .13 .000898-1 / 002 ; 1.0245 .12 .000559-1 / 002$; $1.0290 .05 .025636-8 / 001 ; 1.0324 .12 .006962-4 / 002 ; 1.0324 .14 .004900-2 / 002 ; 1.0377 .13 .001901-3 / 001$; 1.0024.15.209676-4/001.

6 Em referência às UMEIs, Mayrce Freitas, gerente de Coordenação da Educação Infantil da Prefeitura de Belo Horizonte, afirma que "a procura aumenta em função do reconhecimento da qualidade do ensino que é ofertado. [...] a procura tem aumentado principalmente em regiões mais favorecidas. As listas de pretendentes a vagas são grandes, e a procura da classe média é maior do que nas áreas mais vulneráveis." (FERREIRA; KIEFER, 2016, online).

\section{REFERÊNCIAS}

BELO HORIZONTE (Município). Câmara Municipal. Lei Orgânica do Município de Belo Horizonte. 1990. Disponível em: < https:/www.cmbh.mg.gov.br/atividade-legislativa/ pesquisar-legislacao/lei-organica $>$. Acesso em: 19 set. 2017.

. Portaria no 239/2016 da SMED - Secretaria Municipal de Educação do Município de Belo Horizonte, de 10 de agosto de 2015. Dispõe sobre as diretrizes e procedimentos para a organização do processo de inscrição e preenchimento de vagas para as faixas etárias de 
0 a 3 anos para o ano de 2017. Diário Oficial do Município, 10 ago. 2015. Disponível em: $<$ http://portal6.pbh.gov.br/dom/iniciaEdicao.do?method=DetalheArtigo\&pk=1167005>. Acesso em:1 jul. 2017.

. Sítio eletrônico da Prefeitura de Belo Horizonte. PBH adota sistema de Parceria Público-Privada e amplia atendimento na educação municipal. Disponível em: <http:// portalpbh.pbh.gov.br/pbh/contents.do? evento $=$ conteudo\&idConteudo $=117978 \& \mathrm{chP}$ lc $=117978>$. Acesso em: 3 jul. 2017.

BRASIL. Constituição da República Federativa do Brasil de 1988. Presidência da República, Brasília, DF, 1988. Disponível em: <http://www.planalto.gov.br/ccivil_03/constituicao/ constituicaocompilado.htm>. Acesso em 28 jun. 2017.

BRASIL. Lei no 8.069, de 13 de julho de 1990. Dispõe sobre o Estatuto da Criança e do Adolescente e dá outras providências. Presidência da República, Brasília, DF, 13 jul. 1990. Disponível em: <http://www.planalto.gov.br/ccivil_03/leis/L8069.htm>. Acesso em: 19 set. 2017.

BRASIL. Lei n ${ }^{\circ}$ 9.394, de 20 de dezembro de 1996. Estabelece as diretrizes e bases da educação nacional. Presidência da República, Brasília, DF, 20 dez. 1996. Disponível em: < http:// www.planalto.gov.br/ccivil_03/leis/L9394.htm >. Acesso em: 19 set. 2017.

BRASIL. Lei n ${ }^{\circ}$ 10.836, de 9 de janeiro de 2004. Cria o Programa Bolsa Família e dá outras providências. Presidência da República, Brasília, 9 jan. 2004. Disponível em: <http://www. planalto.gov.br/ccivil_03/_ato2004-2006/2004/lei/110.836.htm>. Acesso em: 7 jul. 2017.

BRASIL. Superior Tribunal de Justiça. REsp no 1.185.474-SC. Relator: Min. Humberto Martins. Santa Catarina, 20 de abril de 2010. Diário de Justiça, 29 abr. 2010b. Disponível em: <https://ww2.stj.jus.br/jurisprudencia/externo/informativo/?acao $=$ pesquisar\&livre $=1$ 185474\&operador $=\mathrm{e} \& b=I N F J \&$ thesaurus $=J U R I D I C O$. Acesso em: 4 jul. 2017.

BRASIL. Superior Tribunal de Justiça. REsp n ${ }^{\circ}$ 510.598. Relator: Ministro João Otávio de Noronha, Segunda Turma. São Paulo, 17 de abril de 2007. Diário de Justiça, p. 148, 13 fev. 2008a. Disponível em: $<$ http://www.stj.jus.br/SCON/jurisprudencia/toc.jsp?livre $=\% 22$ educa $\%$ E7\%E3o\%22 + e $+\% 22$ direito + subjetivo $\% 22+e+\% 22$ creche $\% 22 \& \& b=A C O R \&$ thesaurus $=J U R I D I C O \& p=$ true $>$. Acesso em: 19 set. 2017.

BRASIL. Superior Tribunal de Justiça. REsp n ${ }^{\circ}$ 577.573/SP. Relator: Ministro João Otávio de Noronha, Segunda Turma. São Paulo, 17 de abril de 2007. Diário de Justiça, 6 nov. 2008b. Disponível em: <http://www.stj.jus.br/SCON/jurisprudencia/toc.jsp?livre=\%22ed uca $\%$ E7\%E3o\%22+e+\%22direito +subjetivo $\% 22+e+\% 22$ creche $\% 22 \& \& b=A C O R \&$ th esaurus $=J U R I D I C O \& p=$ true $>$. Acesso em: 19 set. 2017.

BRASIL. Supremo Tribunal Federal. RE no 384.201 AgR. Relator: Min. Marco Aurélio, Primeira Turma. São Paulo, 26 de abril de 2007. Diário de Justiça, p. 80, ago. 2007. Disponível em: <http://www.stf.jus.br/portal/jurisprudencia/visualizarEmenta.asp?s1 =000005 439\&base $=$ baseAcordaos $>$. Acesso em: 4 jul. 2017. 
BRASIL. Supremo Tribunal Federal. RE no 464.143 AgR. Relator: Min. Ellen Gracie. São Paulo, 15 de dezembro de 2009. LEXSTF, v. 32, n. 375, 2010a, p. 161-164 fev. 2010. Disponível em: <http://www.stf.jus.br/portal/jurisprudencia/listarJurisprudencia. asp?s1 =\%28464143. NUME. + OU + 464143.ACMS.\%29\&base $=$ baseAcordaos\&url $=$ ht tp://tinyurl.com/zzbuk2o>. Acesso em: 19 set. 2017.

BRASIL. Portal Brasil.Em 12 anos, Bolsa Família retirou 36 milhões de pessoas da pobreza extrema. 2015. Disponível em: <http://www.brasil.gov.br/cidadania-e-justica/2015/10/ em-12-anos-bolsa-familia-retirou-36-milhoes-de-pessoas-da-pobreza-extrema $>$. Acesso em: 7 jul. 2017.

CALGARO, Cleide; PEREIRA, Agostinho Oli Koppe. Políticas públicas e cooperação social em John Rawls. Revista Veredas do Direito, Belo Horizonte, v. 14, n. 28, p. 277-302, jan./ abr. 2017. Disponível em: <http://www.domhelder.edu.br/revista/index.php/veredas/article/ view/970/547>. Acesso em: 3 jul. 2017.

CHOI, Soo-Hyang. Financiamento da educação infantil: perspectiva internacional. Brasília: UNESCO Brasil, 2004. Disponível em: <http://unesdoc.unesco.org/ images/0013/001343/134388por.pdf>. Acesso em: 3 jul. 2017.

CUSTÓDIO, Maraluce Maria; OLIVEIRA, Márcio Luís de. Eco-efficiency in bidding processes to purchase everyday supplies for the Brazilian federal administration. Revista Veredas do Direito, Belo Horizonte, v. 12, n. 24, p. 33-61, jul./dez. 2015. Disponível em:<http://www. domhelder.edu.br/revista/index.php/veredas/article/view/647/454> . Acesso em: 5 jul. 2017.

FERREIRA, Pedro; KIEFER, Sandra. Cresce procura de famílias de classe média por vagas em umeis de BH. Estado de Minas, Belo Horizonte, 12 set. 2016. Disponível em: <http://www. em.com.br/app/noticia/especiais/educacao/2016/09/12/internas_educacao,803035/cresce-procura-de-familias-de-classe-media-por-vagas-em-umeis-de-bh.shtml >. Acesso em: 1 jul. 2017.

FRIEDMAN, Milton. Colocando o aprendizado de volta na sala de aula. Tradução livre de "Putting Learning Back in the Classroom." Nova York: Escola de Harlem, 1977. Vídeo. 74 min. color. son. Disponível em: <https://miltonfriedman.hoover.org/objects/57217>. Acesso em: 2 jul. 2017.

GALDINO, Flávio. Introdução à teoria dos custos dos direitos: direitos não nascem em árvores. Rio de Janeiro: Lumen Juris, 2005.

HOWLETT, Michael; RAMESH, M.; PERL, Anthony. Política pública: seus ciclos e subsistemas, uma abordagem integral. 3. ed. Rio de Janeiro: Elsevier, 2013.

IBGE - Instituto Brasileiro de Geografia e Estatística. Censos Educacionais 2005, 2009, 2012 e 2015, do INEP: Ministério da Educação, Instituto Nacional de Estudos e Pesquisas Educacionais. Disponível em: $<$ http://cidades.ibge.gov.br/xtras/perfil. php?lang=\&codmun=310620 >. Acesso em: 4 jul. 2017. 
KERSTENETZKY, Celia Lessa. O Estado do bem-estar social na idade da razão: a reinvenção do Estado social no mundo contemporâneo. Rio de Janeiro: Elsevier, 2012.

LOPES, Mikhail. Pelo direito de escolher. Super Interessante, São Paulo, 30 jun. 2003. Disponível em: < https://super.abril.com.br/cultura/pelo-direito-de-escolher/>. Acesso em: 10 jul. 2017.

MINAS GERAIS (Estado). Tribunal de Justiça de Minas Gerais. Apelação cível/Rem Necessária 1.0024.16.043475-9/001. Relator: Des. Judimar Biber, 3a Câmara Cível. Minas Gerais, 22 de junho de 2017. TJMG, 18 jul. 2017. Disponível em: < http://www5.tjmg.jus. br/jurisprudencia/pesquisaPalavrasEspelhoAcordao.do? \&numeroRegistro $=8 \&$ totalLinha $s=32$ \&paginaNumero $=8$ \&linhasPorPagina $=1$ \&palavras $=\% 2522$ umei $\% 2522 \% 20 \mathrm{E} \% 20$ $\% 2522$ belo\%20horizonte\%2522\&pesquisarPor $=$ ementa\&pesquisaTesauro $=$ true\&orderB yData $=1$ \& referenciaLegislativa =Clique\%20na\%20lupa \%20para\%20pesquisar\%20as\%20 refer\%EAncias\%20cadastradas...\&pesquisaPalavras=Pesquisar\& $>$. Acesso em: 19 set. 2017. MINAS GERAIS (Estado). Tribunal de Justiça de Minas Gerais. Apelação cível/Rem Necessária n ${ }^{\mathrm{O}}$ 1.0024.15.209676-4/001. Relator: Des. Afrânio Vilela, 2a Câmara Cível. Minas Gerais, 27 de setembro de 2016. TJMG, 7 out. 2016. Disponível em: < http://www5. tjmg.jus.br/jurisprudencia/pesquisaNumeroCNJEspelhoAcordao.do;jsessionid = 5C0942375 46CFB4259F904F312CD1EC3.juri_node2? numeroRegistro $=1 \&$ totalLinhas $=1$ \&linhasPo rPagina $=10 \&$ numeroUnico $=1.0024 .15 .209676-4 \% 2 F 001 \&$ pesquisaNumeroCNJ = Pesqui sar>.Acesso em:19 set. 2017.

OHCHR. Assembleia Geral das Nações Unidas em Paris. Declaração Universal dos Direitos Humanos. 1948. Disponível em: <http:/www.ohchr.org/EN/UDHR/Documents/ UDHR_Translations/por.pdf>. Acesso em: 4 jul. 2017.

OLIVEIRA, Marcio Luís de. A constituição juridicamente adequada: transformações do constitucionalismo e atualização principiológica dos direitos, garantias e deveres fundamentais. 2. ed. Belo Horizonte: Arraes Editores, 2016.

ROCKWELL, Lew. Vouchers escolares: o caminho mais "eficiente" para a socialização da educação. São Paulo: Instituto Ludwig von Mises Brasil, 2014. Disponível em: < http:// www.mises.org.br/Article.aspx?id=1942>. Acesso em: 6 jul. 2017.

SOUZA, Washington Peluso Albino de. Primeiras linhas de direito econômico. 6. ed. São Paulo: LTr, 2005.

WONNACOTT, Paul; WONNACOTT, Ronald. Introdução à economia. São Paulo: McGraw-Hill do Brasil, 1985.

Submetido: 18 ago. 2017

Aprovado: 18 set. 2017 